\title{
Gluten free pasta with natural ingredient of color and carotene source
}

\author{
Massas sem glúten com ingredientes naturais como fonte de cor e carotenoides \\ Pasta sin gluten con ingredientes naturales como fuente de color y carotenoides
}

Received: 03/16/2021 | Reviewed: 03/23/2021 | Accept: 03/29/2021 | Published: 04/08/2021

\author{
Michele Scarton \\ ORCID: https://orcid.org/0000-0001-8396-219X \\ Universidade Estadual de Campinas, Brazil \\ E-mail: michele.scarton@yahoo.com.br \\ Tatiane Godoy Ribeiro \\ ORCID: https://orcid.org/0000-0002-1780-6567 \\ Universidade Estadual de Campinas, Brazil \\ E-mail: tatiane.godoy.ribeiro@gmail.com \\ Helena Teixeira Godoy \\ ORCID: https://orcid.org/0000-0003-4339-5463 \\ Universidade Estadual de Campinas, Brazil \\ E-mail: helenatg@unicamp.br \\ Jorge Herman Behrens \\ ORCID: https://orcid.org/0000-0002-3952-1722 \\ Universidade Estadual de Campinas, Brazil \\ E-mail: behrens@unicamp.br \\ Pedro Henrique Campelo \\ ORCID: https://orcid.org/0000-0002-4048-3858 \\ Universidade Federal do Amazonas, Brazil \\ E-mail: pedrocampelo@ufam.edu.br \\ Maria Teresa Pedrosa Silva Clerici \\ ORCID: https://orcid.org/0000-0002-8445-336X \\ Universidade Estadual de Campinas, Brazil \\ E-mail: mclerici@unicamp.br
}

\begin{abstract}
The gluten-free pasta (GFP) has a higher cost and is often brittle, pale, and poorly balanced in macro and micronutrients when compared to wheat-based pasta. This study aimed to use the biofortified sweet potato flour, a natural source of color and provitamin A ingredient, with rice flour, hydrolyzed soy protein concentrate, and carboxymethyl cellulose gum to produce GFP, using a central composite rotatable design with three factors $\left(2^{3}\right)$ and the central point. The GFP were evaluated by instrumental color analysis, and visual analysis of technological characteristics (presence of cracks, defect, and shape aspect), used for selection. Three GFP were selected: E1, E2 and E12, which showed absence of breaks or defects and an intermediate aspect after cooking, which were submitted to nutritional, functional and sensory evaluations. These GFPs presented levels of $\beta$-carotene of 135.22, 292.04 and $147.54 \mu \mathrm{g} / \mathrm{g}$ (dry basis), respectively, and showed sensory overall liking means in the acceptance region $(>4.5)$ with no significant differences among them. According to the penalty analysis, the parameters color and consistency penalized these averages. Therefore, optimizing the ingredients' concentrations improved the nutritional value and the sensory acceptability of GFP.
\end{abstract}

Keywords: Cereals; Tuber; Gluten-free product; $\beta$-carotene.

\section{Resumo}

A massa sem glúten (MSG) tem um custo mais elevado e muitas vezes é quebradiça, pálida e pouco balanceada em relação aos macros e micronutrientes quando comparada à massa à base de trigo. Este estudo teve como objetivo usar uma farinha biofortificada de batata doce, uma fonte natural de cor e ingrediente pró-vitamina A, com farinha de arroz, concentrado de proteína de soja hidrolisada e goma de carboximetilcelulose para produzir MSG, usando um design rotativo composto central com três fatores $\left(2^{3}\right)$ e o ponto central. As MSG foram avaliadas por análise instrumental de cor e análise visual das características tecnológicas (presença de fissuras, defeito e aspecto de formato), utilizadas para a seleção. Foram selecionadas três MSG: E1, E2 e E12, que apresentaram ausência de quebras ou defeitos e formato intermediário após o cozimento, as quais foram submetidas a avaliações nutricionais, funcionais e sensoriais. Essas MSG apresentaram níveis de $\beta$-caroteno de 135,22, 292,04 e 147,54 $\mu \mathrm{g} / \mathrm{g}$ (base seca), respectivamente, e apresentaram médias de sabor e aceitação global na região de aceitação $(>4,5)$, sem diferenças significativas entre estas. De acordo com a análise de penalidade, os parâmetros cor e consistência penalizaram essas médias. Portanto, otimizar as concentrações dos ingredientes melhorou o valor nutricional e a aceitabilidade sensorial das MSG.

Palavras-chave: Cereais, Tubérculos, Produto sem glúten, $\beta$-caroteno. 


\begin{abstract}
Resumen
La pasta sin gluten (PSG) tiene un costo más elevado y suele ser más quebradiza, pálida y menos balanceada en macro y micronutrientes en comparación con la pasta a base de trigo. Este estudio tuvo como objetivo utilizar la harina de camote biofortificado, como ingrediente fuente de color y pro-vitamina A, con harina de arroz, concentrado de proteína de soya hidrolizada, y goma de carboximetilcelulosa para producir PSG, usando un diseño central compuesto rotacional con tres factores $\left(2^{3}\right)$ y un punto central. Las PSG fueron evaluadas en cuanto a sus características tecnológicas visuais (ausencia de roturas o defectos, y aspecto de forma intermedia después de la cocción). Tres de ellas fueron seleccionados para evaluación nutricional y sensorial: E1, E2 y E3. Las pastas mostraron niveles de $\beta$-caroteno de 135,22, 292,04 y $147,54 \mu \mathrm{g} / \mathrm{g}$ (en base seca), respectivamente, e tuvieron promedios de sabor y aceptación general dentro de la región de aceptación (>4.5), sin diferencias significativas entre ellas. De acuerdo con el análisis de penalidad, fueron los parámetros como el color y la consistencia los que penalizaron estos puntajes. Por lo tanto, la optimización de la concentración de los ingredientes mejoró el valor nutricional y la aceptabilidad sensorial de las PSG.
\end{abstract}

Palabras clave: Cereales; Tubérculos; Productos gluten-free; $\beta$-caroteno.

\title{
1. Introduction
}

The hidden hunger is characterized when the absorption or consumption of essential micronutrients is below the level required for maintaining health conditions (Gödecke et al., 2018). According to the United Nations Children's Fund - UNICEF - report (UNICEF, 2019), at least 340 million preschool-age children suffer from hidden hunger worldwide. These individuals may have their immune systems compromised, worsening symptoms of contagious diseases, such as the new coronavirus SARSCoV-2 (Kissler et al., 2020). To mitigate this global problem, the action of organizations like Harvest Plus stands out, which leads the development and diffusion of vegetables biofortified in vitamin A, iron, and zinc in the most affected by hidden hunger developing countries of Central America, Africa, and Asia (Nutti, 2003), and celiac people (Lamacchia et al., 2014).

In Latin America, Brazil is one of the countries attended by the Harvest Plus Challenge Program, coordinated by the Brazilian Agricultural Research Corporation - EMBRAPA, where biofortified sweet potato 'Beauregard' (BSP) has been planted and consumed in locations among low-income populations (Nutti, 2003). The biofortified sweet potato has a soft and orangecolored pulp due to its high content of $\beta$-carotene - $115 \mu \mathrm{g} / \mathrm{g}$ of fresh BSP roots (Berni et al., 2015). Thus, the BSP can be used to provide the energy supply and the necessary micronutrients for restricted diets (Taylor \& Duodu, 2017). However, the BSP consumption is still limited and actions are needed to increase its consumption, such as flour processing, as reported by Souza et al. (2020), allowing an increase of its shelf-life and an easier inclusion as an ingredient in food products. There is also a growing interest in the use of the BSP as a source of natural coloring and biocomponents in gluten-free products, for example in pre-mixes for breads (Julianti et al., 2017), and cookies (Sousa et al., 2020). There is a crescent interest in the use of naturalcoloring ingredients with a health appeal in pastas, as studied by Wahanik et al. (2021) for whole wheat pastas, what could be developed also for GFPs.

The production of gluten-free foods remains a challenge for the food industry. In general, GFPs, especially those formulated with cereal flours and starches, exhibits technological defects, such as brittle structure, pale coloring, and excessive stickiness after cooking, as reported by Ferreira et al. (2016) and Bouasla et al. (2017), who studied GFPs formulated with corn starch and rice flour, respectively. The GFPs could also present nutritional limitations in some amino acids (lysine and tryptophan) and micronutrients, such as vitamins A, C, and D, and minerals, as iron, calcium, and magnesium (Brouns et al., 2013).

The synergistic effect of ingredients from different sources, such as roots, cereals, tubers, and legumes, contributes to the nutritional and cooking quality of GFPs as reported by Marti and Pagani (2013) in a review on the use of ingredients for the structuring of the GFPs. Proteic ingredients, such egg white could be used for better GFPs structuration, as used by Campos \& Almeida (2020), for GFP based on taro flour, with addition of transglutaminase enzyme. For this purpose, and also for complementation of limiting amino acids of the GFPs that are based on cereal starch and flours, ingredients from legume plants can be used. The soy protein hydrolysate, for example, presents high protein content and can be used in food products, and, 
according to Sun (2011), offer the advantage of reducing the allergenicity of soybean favoring the protein digestibility. Gums and emulsifiers are the additives widely used in GFP. Gums can help to structure and reduce the loss of solids of GFP, interacting with the starch and protein fractions (Xue \& Ngadi, 2007). The emulsifiers can provide lubrication in the extrusion processes and contribute to less adhesion and structure maintenance of the GFP.

Therefore, this study aimed to produce and evaluate fusilli-type rice-based GFP, with a biofortified sweet potato flour (BSPF), hydrolyzed soy protein concentrate (HSPC), sodium carboxymethyl cellulose gum (CMC), and monoglycerides. The best GFPs were selected to evaluate functional and sensory characteristics.

\section{Methodology}

\subsection{Material}

The following ingredients were used to produce the GFP: BSPF: the BSP was washed, sanitized in a disinfectant solution (200 mg/kg of sodium hypochlorite), cut into cubes $\left(2.25 \mathrm{~cm}^{3}\right)$, heat-bleached, freeze-dried in Liotop LP820 freeze-dryer (Liobras, São Carlos, SP, Brazil) for 72 hours, and ground until obtaining flour, which was packed in polystyrene film bags coated with $1.5 \mathrm{~g} / 100 \mathrm{~g}$ of titanium dioxide. Other ingredients: RF (SL Alimentos, Mauá da Serra, PR, Brazil); HSPC (Immunoprotein ${ }^{\circledR}$ HT Nutri, Camaquã, RS, Brazil); CMC (Cekol® 30.000B CPKelco, Limeira, SP, Brazil); distilled monoglycerides (DIMODAN® PH 100 NS/B DuPont Danisco, Grindsted, DK, Denmark).

\subsection{Methods}

\subsubsection{Physicochemical characterization of raw materials}

The proximate composition of RF, BSPF, and HSPC was determined according to the methodology of the Association of Official Analytical Chemists (AOAC, 2005) for moisture (926.12), proteins (945.18), ash (942.05), and lipids in ethereal extract (920.39). The total carbohydrates content was calculated by difference. The total dietary fiber of BSPF was quantified by the enzymatic-gravimetric method, using a Megazyme ${ }^{\circledR}$ K-TDFR 05/12 kit (Megazyme, Wicklow, Ireland), according to the methods 985.29 (AOAC, 2006) and 32-21.01 of the American Association of Cereal Chemists (AACCI, 2010). All experiments were carried out in triplicate.

\subsubsection{Experimental design}

The proportions of the ingredients to produce GFP were established using a central composite rotatable design (CCRD) with three factors $\left(2^{3}\right)$ and three repetitions of the central point, totaling 17 assays, as shown in Table 1. The three independent variables were: RF:BSPF ratio, and the HSPC and the CMC quantities. Distilled monoglycerides ( $1 \mathrm{~g} / 100 \mathrm{~g}$ of flour basis - f.b.) were also added to all formulations.

\subsubsection{Production of gluten-free pasta}

The dry ingredients were mixed for 5 minutes in a planetary mixer (Arno, São Paulo, Brazil) and water (45g/100g) was added during this step. The GFPs were produced by cold extrusion (batches of 400g) using a Pastaia II extruder with a screw matrix for fusilli pasta shape (Italvisa, Tatuí, São Paulo, Brazil), and the cutting speed was adjusted to an average size of 2 to $3 \mathrm{~cm}$. The GFPs were oven-dried (model TE-394/2, Tecnal, Piracicaba, Brazil) at temperatures ranging from $45^{\circ} \mathrm{C}$ to $55^{\circ} \mathrm{C}(\leq 60$ Relative Humidity) until moisture content below $14 \mathrm{~g} / 100 \mathrm{~g}$. The GFPs were packaged in tri-layered polyethylene film bags for protection from light and stored at $20^{\circ} \mathrm{C}$. 


\subsubsection{Quality assessment of gluten-free pasta}

The following parameters were considered as the dependent variables for assessing the technological quality of GFP: Visual selection: once there are no technological standards for raw GFPs, a classification was developed based on visual inspection and measurement, as showed in Table 1. For that, 15 units of GFPs were sampled and the size $(\mathrm{cm})$, diameter $(\mathrm{mm})$, and distance between threads of a fusilli' screw (pitch) were measured with a digital caliper. The classification was made according to defects, breaks, and shape characteristics using the parameters described in Table 1 and Figure 1.

Table 1. Technological characteristics of fusilli-type gluten-free pastas ${ }^{\mathrm{a}}$

\begin{tabular}{|c|c|c|}
\hline Attribute & Definition & Classification $^{\mathrm{b}}$ \\
\hline Unit size & Unit size of GFP, measured in centimeters & N.A. \\
\hline Diameter & Diameter of unit of GFP, measured in centimeters & N.A. \\
\hline \multirow{3}{*}{ Defects } & \multirow{3}{*}{ Presence of defects in the shape of GFP. } & Flawless: no apparent defects (desirable) \\
\hline & & $\begin{array}{l}\text { Mild defects: defects in shape that do not severely compromise the } \\
\text { structure }\end{array}$ \\
\hline & & $\underline{\text { Severe defects: }}$ defects that compromise the structure \\
\hline \multirow{3}{*}{ Cracks } & \multirow{3}{*}{ Presence of fractures in the GFP unit. } & Flawless: no apparent cracks (desirable) \\
\hline & & $\begin{array}{l}\text { Mild cracks: presence of slight breaks that do not compromise the } \\
\text { structure }\end{array}$ \\
\hline & & $\underline{\text { Severe cracks: }}$ presence of breaks that compromise the structure \\
\hline \multirow[t]{2}{*}{ Pitch } & $\begin{array}{l}\text { Distance between threads of a screw. Measurement between the } \\
\text { threads of the fusilli GFP, in millimeters. }\end{array}$ & N.A. \\
\hline & & Narrow: pitch $>0.5 \mathrm{~mm}$ and $<0.6 \mathrm{~mm}$ \\
\hline \multirow[t]{2}{*}{ Shape aspect } & Description of the shape based on threads distance and visual aspect & Intermediate: pitch $>0.61 \mathrm{~mm}$ and $<0.70 \mathrm{~mm}$ (desirable) \\
\hline & & Wide: pitch $>0.71 \mathrm{~mm}$ \\
\hline
\end{tabular}

${ }^{\mathrm{a} G F P}$ : gluten-free pastas. ${ }^{\mathrm{b}}$ N.A: Not applicable. Source: Authors.

Figure 1. Visual parameters for technological evaluation and classification of fusilli-type gluten-free pastas (GFPs); (a): Cracks; (b): Defects of format;(c) Characteristics of shape.

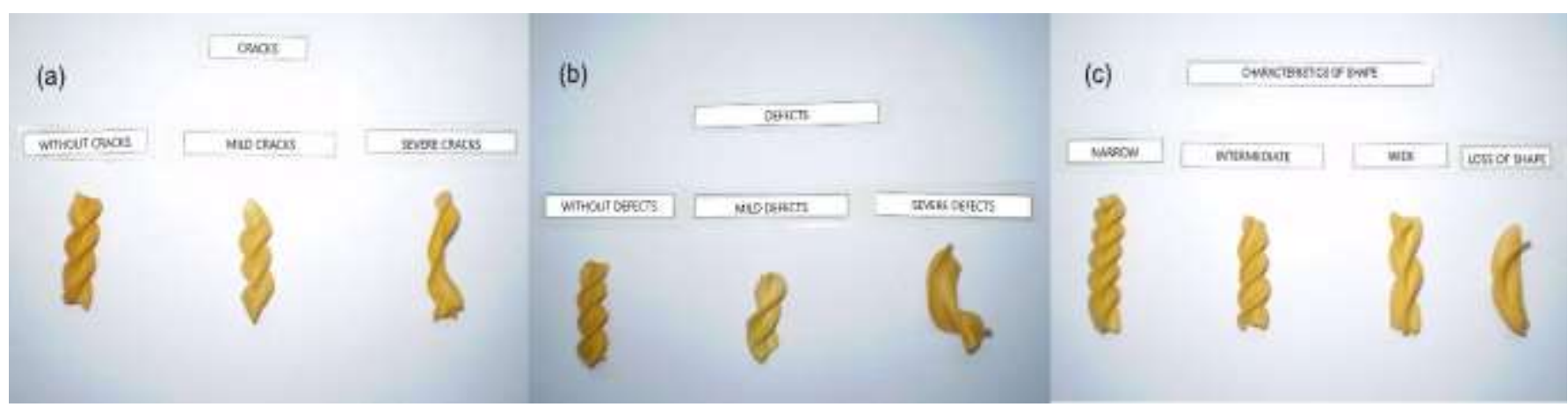

Source: Authors.

Color evaluation: the GFPs were cooked at the optimum cooking time, previously determined, which was about 180 seconds, and instrumental color parameters were assessed in GFPs before and after cooking, using a Konica Minolta CR-400 45-OL portable colorimeter (Konica Minolta Sensing Inc., Osaka, Japan) with standard calibration and D65 illuminant. The parameters $\mathrm{L}^{*}, \mathrm{a}^{*}$, and $\mathrm{b}^{*}$ were obtained by the CIELab system. The color differences $(\Delta \mathrm{E})$ before and after cooking were determined as reported by Mokrzycki and Tatol (2011). All experiments were carried out in triplicate. Data were presented as mean \pm standard deviation, and the correlations between the independent variables were assessed through analysis of variance 
(ANOVA), observing the significance (p-value) of the regression and lack of adjustment at 0.05 significance level by the F-test. For significant models, the response surfaces were obtained using the Protimiza Statistical software. The coefficient of determination $\left(\mathrm{R}^{2}\right)$ was calculated, and the closer to the value 1 , the better the model fit the data. Those models with significant p-value and non-significant lack of fit at a 0.05 significance level, with $\mathrm{R}^{2}$ greater than 0.80 were considered as predictive models. For significant regression models with high $\mathrm{R}^{2}$ value and lack of fit, the mean square pure error was analyzed by the modified ANOVA.

\subsubsection{Technological selection}

The desirable technological characteristics for best GFPs were the absence of breaks or defects and the ideal shape aspect after cooking.

\subsubsection{Physicochemical characterization}

The selected GFPs were characterized for their proximate composition according to the methodology of AOAC (2005) for moisture (926.12), proteins (945.18), ash (942.05), and lipids in ethereal extract (920.39). All experiments were carried out in triplicate. The total dietary fiber content of the GFPs was calculated considering only the BSPF as an ingredient source, and the total carbohydrates content was calculated by difference [100 - (moisture + proteins + lipids + ash + total dietary fiber)].

\subsubsection{Functional characterization of $\beta$-carotene}

The quantification of $\beta$-carotene was performed to characterize the functional properties of the selected GFPs. A $\beta$ carotene standard was obtained according to the methodology of Rodrigues-Amaya and Kimura (2004), extracted from 80g of crushed carrots. This method was also used for cooked GFPs (20g of the sample, weight on a wet basis). The extracts of the GFPs were resuspended in $2 \mathrm{~mL}$ of solvent (acetonitrile: methanol: ethyl acetate, 60:20:20) as described by Bohoyo-Gil et al. (2012). The chromatographic separation was performed on a HypersilGoldTM C18 column (100 mm height; $2.1 \mathrm{mmwidth}$, particle diameter $1.9 \mu \mathrm{m}$, Thermo Scientific, Waltham, MA, USA), using the Agilent 1260 High-Performance Liquid Chromatography (HPLC, Agilent Technologies, California, USA), equipped with a quaternary pump, automatic injector, degasser, thermostatic column oven, and diode array detector (DAD). The chromatographic conditions were adjusted according to Cardenas-Toro et al. (2015). Data were obtained in the AgilentTM 1100 software and the identification of $\beta$-carotene was carried out by comparing the retention times and absorption spectra (UV-VIS) at $450 \mathrm{~nm}$ with the $\beta$-carotene standard. A standard curve made with $\beta$-carotene concentrations ranging from $2.2 \mu \mathrm{g} / \mathrm{mL}$ to $4.84 \mu \mathrm{g} / \mathrm{mL}$ was constructed, with sample dilutions to fit the curve. The GFP extracts were diluted (1:2 dilution) and filtered through a $0.2 \mu \mathrm{m}$ membrane before injection. All analyses were performed in duplicate. Data were presented as mean \pm standard deviation, and the regression equations and $\mathrm{R}^{2}$ values were calculated using Excel software, considering an $\mathrm{R}^{2}$ greater than 0.95 .

\subsubsection{Sensory evaluation}

The sensory evaluation of the selected GFPs was carried out at the University of Campinas, UNICAMP (Campinas, SP, Brazil), upon the approval of the Research Ethics Committee (CAAE 58561716.4.0000.5404). Fifty-seven ( $=57)$ pasta consumers, aged between 18 and 60 years, were invited to participate in the test. First, it was applied a questionnaire about the consumption habits of the assessors (Figure 2).

Then, raw and cooked GFPs were evaluated. Raw GFPs: the samples were presented in individual transparent polyethylene bags, identified by a three-digit code for the evaluation of appearance, and evaluated by a methodology adapted from Morais et al. (2014), using a 9-cm unstructured Just-About-Right (JAR) scale, with the ideal point in the middle $(4.5 \mathrm{~cm})$. 
The assessors should rate the visual color of the GFPs as following: 0 to $4.4 \mathrm{~cm}$ corresponded to "too much light color"; $4.5 \mathrm{~cm}$, "JAR"; and 4.6 to 9cm, "too much dark color". Cooked GFPs: a 10g sample (cooked with $1 \mathrm{~g}$ of refined salt) identified with three-digit code (as used for the raw GFPs) were presented to consumers for evaluation of appearance, aroma, texture, and overall liking using a 9-point hedonic scale (Meilgaard, et al., 2000). The color was evaluated by the JAR scale, as used for the raw GFPs, texture, where: 0 to $4.4 \mathrm{~cm}$ corresponded to "too much soft"; $4.5 \mathrm{~cm}$, "JAR"; and 4.6 to $9 \mathrm{~cm}$, "too much firm". The data were evaluated by analysis of variance (ANOVA) and Tukey's test $(\mathrm{p}<0.05)$, and the JAR scale was evaluated by the penalty analysis (Lawless \& Heymann, 2010), both were performed using the XLStat software, version 2014.

Figure 2. Questionnaire applied to assesors.

SENSORY EVALUATION OF GLUTEN FREE PASTA - PROJECT APPROVED (CAAE 58561716.4.0000.5404)

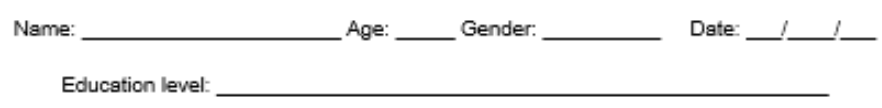

\begin{tabular}{l} 
Which are your favorite pasta shapes? (you can choose more than one option) \\
J have no preference for a specific pasta shape \\
JFusill \\
JFarfalle \\
Jenne \\
Jpaghett \\
Howner shapes: \\
Every day \\
At least 3 or 4 times a week \\
At least 1 or 2 times a week \\
Once every 15 days \\
\hline Once every month
\end{tabular}

\begin{tabular}{|c|c|}
\hline Fresh homemade pasta & Whole-wheat pssta \\
\hline Fresh commercial pasta & Semolina pasta \\
\hline Dry pasta & Egg posts \\
\hline Instant noodes & Multi-colored pasta \\
\hline \multicolumn{2}{|c|}{ Have you consumed or ususlly consume gluten-free pasta? } \\
\hline \multicolumn{2}{|c|}{ I have never consumed } \\
\hline \multicolumn{2}{|l|}{ Yes, I have consumed once } \\
\hline \multicolumn{2}{|c|}{ Yes, I usually consume } \\
\hline \multicolumn{2}{|c|}{ Yes, I only consume gluten-free pasta } \\
\hline \multicolumn{2}{|c|}{ If you have consumed or usually consume gluten-free pasta, which pasta do you prefer? } \\
\hline \multicolumn{2}{|c|}{ I do not usually consume gluten-free pasta } \\
\hline \multicolumn{2}{|c|}{ I do not have any specific preference } \\
\hline \multicolumn{2}{|c|}{ 口ice-based } \\
\hline a Com-based & \\
\hline
\end{tabular}

Source: Authors.

\section{Results and Discussion}

\subsection{Physicochemical characterization of the ingredients}

As shown in Table 2, the chemical composition of RF, BSPF, and HSPC was similar to those described by Bouasla et al. (2017), Berni et al. (2015) and Limroongreungrat and Huang (2007), respectively. 
Table 2. Chemical composition of the rice flour, biofortified sweet potato flour, and hydrolyzed soy protein concentrate ${ }^{\mathrm{a}}$

\begin{tabular}{cccc}
\hline & & Raw Material $^{\mathbf{b}}$ & \\
\hline Compounds(g/100g) & RF & BSPF & HSPC \\
\hline Moisture & $11.43 \pm 0.10$ & $14.49 \pm 0.39$ & $9.28 \pm 0.17$ \\
Dry matter & 88.57 & 85.51 & 90.72 \\
\hline Protein & $13.54 \pm 0.33$ & $6.03 \pm 0.51$ & $68.75 \pm 2.14$ \\
Lipids & $1.32 \pm 0.21$ & $0.99 \pm 0.15$ & $0.66 \pm 0.08$ \\
Ash & $0.62 \pm 0.02$ & $3.39 \pm 0.58$ & $8.98 \pm 0.09$ \\
Carbohydrates $^{\mathbf{d}}$ & 73.09 & 62.08 & 12.33 \\
Total dietary fiber $^{\mathrm{e}}$ & $\mathrm{ND}^{\mathrm{e}}$ & $13.02 \pm 0.88$ & ND $^{\mathrm{e}}$ \\
\hline
\end{tabular}

${ }^{a}$ Results were expressed as mean \pm standard deviation (triplicate), on a dry basis. ${ }^{b} \mathrm{RF}$, rice flour; BSPF, biofortified sweet potato flour; HSPC, hydrolyzed soy protein concentrate. ' Different lowercase letters in the same column indicate significant differences ( $\mathrm{p} \leq 0.05)$ by Tukey's test. ${ }^{\mathrm{d}}$ Carbohydrates determined by difference (100 - (moisture+proteins+lipids+ash+total dietary fiber)). ${ }^{\mathrm{e} N D}$ : not determined. Source: Authors.

\subsection{Instrumental color and color differences}

The results of the instrumental color analysis of GFPs and the significant effects are shown in Table 3. Concerning the color of the raw GFPs, a significant and non-predictive $\left(\mathrm{R}^{2}<0.80\right)$ model was obtained only for the color coordinate $\mathrm{b}^{*}$, which was mainly influenced by the increase of the BSPF and proportional reduction of RF quantities, as could be observed in Figure 3 (a). Despite the reduction, the $b^{*}$ values remained positive, which are related to a visual yellow color. For the cooked GFPs, only the color coordinate $\mathrm{a}^{*}$ was considered significant, according to modified ANOVA procedure (Section 2.2.4). The increase in BSPF and proportional reduction of RF was significant for the model proposed, increasing a* values, as observed in the response surface shown in Figure 3(b). The positive a* values are related to the red tone, indicating that BSPF had an important effect on this parameter. The evaluation of the instrumental color was important to understand the role of the conjoint ingredients on the visual aspects of GFPs, and evaluate if the BSPF could be used as a natural color agent. The authors Limroongreungrat \& Huang (2007) studied gluten-free noodles formulated with BSPF and several soy derivatives and obtained color parameters close to those found in our study, showing an orange visual color. All GFPs showed color differences $(\Delta \mathrm{E})$ between them, which were visually evident, probably due to the manufacturing process effects in $\beta$-carotene due to the cooking process. According to Pathare et al. (2013), $\beta$-carotene can change due to oxidation reactions and heat, leading to differences in the color of food before and after cooking, as also reported by Berni et al. (2015), who evaluated the effect of $\beta$-carotene modification on BSP. Thus, through the sensory evaluation, these interpretation of differences in color and consumer's perception could be well understanded. 
Table 3. Color values (CIELab system) and color difference $(\Delta \mathrm{E})$ for raw and cooked fusilli-type gluten-free pasta (GFP).

\begin{tabular}{|c|c|c|c|c|c|c|c|c|c|c|c|c|c|}
\hline \multirow[b]{4}{*}{ GFP $^{a}$} & \multicolumn{6}{|c|}{ Independent variables ${ }^{\text {b }}$} & \multirow{2}{*}{\multicolumn{6}{|c|}{$\frac{\text { Dependent variables }^{\text {c,d }}}{\text { Color parameters }}$}} & \multirow[b]{4}{*}{$\Delta \mathbf{E}$} \\
\hline & \multirow{2}{*}{\multicolumn{3}{|c|}{ Coded values }} & \multirow{2}{*}{\multicolumn{3}{|c|}{ Real values }} & & & & & & & \\
\hline & & & & & & & \multicolumn{3}{|c|}{ Raw GFP } & \multicolumn{3}{|c|}{ Cooked GFP } & \\
\hline & $\begin{array}{c}: B \\
\text { SP } \\
\text { F } \\
\left(\mathbf{x}_{1}\right. \\
)\end{array}$ & $\begin{array}{c}\text { HSP } \\
\text { C } \\
\left(\mathbf{x}_{2}\right)\end{array}$ & $\begin{array}{c}\mathbf{C} \\
\mathbf{M} \\
\mathbf{C} \\
\left(\mathbf{x}_{3}\right)\end{array}$ & $\begin{array}{l}\text { RF:B } \\
\text { SPF } \\
\left(X_{1}\right)\end{array}$ & $\begin{array}{c}\text { HSP } \\
\mathbf{C} \\
\left(\mathbf{X}_{2}\right)\end{array}$ & $\begin{array}{c}\mathbf{C M} \\
\mathbf{C} \\
\left(\mathbf{X}_{3}\right)\end{array}$ & $\mathbf{L}^{*}$ & $a^{*}$ & $\mathbf{b}^{*}$ & $\mathbf{L}^{*}$ & $a^{*}$ & $\mathbf{b}^{*}$ & \\
\hline E1 & -1 & -1 & -1 & $90: 10$ & 5 & 1 & $\begin{array}{c}56.77 \pm 0.2 \\
7\end{array}$ & $\begin{array}{l}14.17 \pm 0.7 \\
3\end{array}$ & $\begin{array}{c}31.13 \pm 0.8 \\
0\end{array}$ & $\begin{array}{c}67.19 \pm 1.5 \\
3\end{array}$ & $\begin{array}{c}13.04 \pm 0 \\
29\end{array}$ & $\begin{array}{c}44.13 \pm 0.2 \\
2\end{array}$ & $\begin{array}{c}16.76 \pm 0.9 \\
4\end{array}$ \\
\hline E2 & 1 & -1 & -1 & $80: 20$ & 5 & 1 & $\begin{array}{c}54.85 \pm 0.7 \\
0\end{array}$ & $\begin{array}{c}17.11 \pm 0.4 \\
6\end{array}$ & $\begin{array}{c}30.01 \pm 0.2 \\
7\end{array}$ & $\begin{array}{c}57.42 \pm 1.3 \\
0\end{array}$ & $\begin{array}{c}18.15 \pm 0 \\
80\end{array}$ & $\begin{array}{c}46.01 \pm 1.4 \\
4\end{array}$ & $\begin{array}{c}16.40 \pm 1.6 \\
7\end{array}$ \\
\hline $\mathbf{E 3}$ & -1 & 1 & -1 & $90: 10$ & 9 & 1 & $\begin{array}{c}55.26 \pm 0.1 \\
3\end{array}$ & $\begin{array}{c}14.21 \pm 0.5 \\
9\end{array}$ & $\begin{array}{c}32.18 \pm 0.3 \\
2\end{array}$ & $\begin{array}{c}66.25 \pm 0.7 \\
9\end{array}$ & $\begin{array}{c}11.78 \pm 0 \\
29\end{array}$ & $\begin{array}{c}39.32 \pm 0.5 \\
2\end{array}$ & $\begin{array}{c}13.40 \pm 0.4 \\
5\end{array}$ \\
\hline E4 & 1 & 1 & -1 & $80: 20$ & 9 & 1 & $\begin{array}{c}48.73 \pm 0.6 \\
0\end{array}$ & $\begin{array}{c}17.65 \pm 1.0 \\
7\end{array}$ & $\begin{array}{c}29.99 \pm 1.0 \\
3\end{array}$ & $\begin{array}{c}60.41 \pm 0.7 \\
9\end{array}$ & $\begin{array}{c}17.51 \pm 0 \\
89\end{array}$ & $\begin{array}{c}43.79 \pm 0.3 \\
7\end{array}$ & $\begin{array}{c}18.26 \pm 0.6 \\
7\end{array}$ \\
\hline $\mathbf{E 5}$ & -1 & -1 & 1 & $90: 10$ & 5 & 3 & $\begin{array}{c}47.40 \pm 0.4 \\
4\end{array}$ & $\begin{array}{c}17.92 \pm 0.3 \\
8\end{array}$ & $\begin{array}{c}35.68 \pm 0.9 \\
3\end{array}$ & $\begin{array}{c}61.72 \pm 1.4 \\
1\end{array}$ & $\begin{array}{l}14.58 \pm 0 \\
22\end{array}$ & $\begin{array}{c}41.46 \pm 0.5 \\
6\end{array}$ & $\begin{array}{c}15.84 \pm 1.5 \\
5\end{array}$ \\
\hline E6 & 1 & -1 & 1 & $80: 20$ & 5 & 3 & $\begin{array}{c}58.61 \pm 0.3 \\
7\end{array}$ & $\begin{array}{c}16.39 \pm 0.7 \\
4\end{array}$ & $\begin{array}{c}30.03 \pm 0.9 \\
9\end{array}$ & $\begin{array}{c}68.17 \pm 0.2 \\
7\end{array}$ & $\begin{array}{c}16.95 \pm 0 \\
28\end{array}$ & $\begin{array}{c}46.04 \pm 0.2 \\
7\end{array}$ & $\begin{array}{c}18.68 \pm 0.8 \\
5\end{array}$ \\
\hline E7 & -1 & 1 & 1 & $90: 10$ & 9 & 3 & $\begin{array}{c}47.80 \pm 0.5 \\
3\end{array}$ & $\begin{array}{c}16.10 \pm 0.1 \\
6\end{array}$ & $\begin{array}{c}34.18 \pm 0.0 \\
5\end{array}$ & $\begin{array}{c}71.56 \pm 0.2 \\
2\end{array}$ & $\begin{array}{c}11.00 \pm 0 \\
22\end{array}$ & $\begin{array}{c}37.90 \pm 0.4 \\
5\end{array}$ & $\begin{array}{c}24.60 \pm 0.4 \\
6\end{array}$ \\
\hline E8 & 1 & 1 & 1 & $80: 20$ & 9 & 3 & $\begin{array}{c}47.64 \pm 0.9 \\
0\end{array}$ & $\begin{array}{c}19.12 \pm 1.1 \\
5\end{array}$ & $\begin{array}{c}29.14 \pm 0.7 \\
6\end{array}$ & $\begin{array}{c}67.53 \pm 0.0 \\
4\end{array}$ & $\begin{array}{c}16.66 \pm 0 \\
08\end{array}$ & $\begin{array}{c}38.69 \pm 0.3 \\
3\end{array}$ & $\begin{array}{c}22.24 \pm 0.6 \\
9\end{array}$ \\
\hline E9 & $\begin{array}{c}- \\
1.6 \\
8\end{array}$ & -1 & 0 & 93.4:6 & 5 & 2 & $\begin{array}{c}56.55 \pm 0.8 \\
1\end{array}$ & $\begin{array}{c}12.35 \pm 0.4 \\
1\end{array}$ & $\begin{array}{c}31.66 \pm 0.3 \\
4\end{array}$ & $\begin{array}{c}72.80 \pm 1.1 \\
4\end{array}$ & $\begin{array}{c}9.73 \pm 0.3 \\
0\end{array}$ & $\begin{array}{l}38.74 \pm 0.5 \\
5\end{array}$ & $\begin{array}{c}17.95 \pm 0.9 \\
0\end{array}$ \\
\hline E10 & $\begin{array}{c}1.6 \\
8\end{array}$ & -1 & 0 & $\begin{array}{c}76.6: 2 \\
3.40\end{array}$ & 5 & 2 & $\begin{array}{c}51.38 \pm 0.4 \\
1\end{array}$ & $\begin{array}{c}17.61 \pm 0.3 \\
4\end{array}$ & $\begin{array}{c}29.10 \pm 0.3 \\
4\end{array}$ & $\begin{array}{c}66.07 \pm 0.5 \\
6\end{array}$ & $\begin{array}{c}18.10 \pm 0 . \\
20\end{array}$ & $\begin{array}{c}45.50 \pm 0.2 \\
1\end{array}$ & $\begin{array}{c}22.05 \pm 0.6 \\
1\end{array}$ \\
\hline E11 & 0 & 0 & $\begin{array}{c}- \\
1.6 \\
8\end{array}$ & $85: 15$ & 3.60 & 2 & $\begin{array}{c}56.73 \pm 0.5 \\
0\end{array}$ & $\begin{array}{c}14.92 \pm 0.1 \\
1\end{array}$ & $\begin{array}{c}30.06 \pm 0.1 \\
7\end{array}$ & $\begin{array}{c}66.58 \pm 1.2 \\
9\end{array}$ & $\begin{array}{c}15.42 \pm 0 \\
17\end{array}$ & $\begin{array}{c}45.09 \pm 0.7 \\
5\end{array}$ & $\begin{array}{c}17.99 \pm 1.5 \\
2\end{array}$ \\
\hline E12 & 0 & 0 & $\begin{array}{c}1.6 \\
8\end{array}$ & $85: 15$ & 10.40 & 2 & $\begin{array}{c}55.67 \pm 1.0 \\
0\end{array}$ & $\begin{array}{c}14.58 \pm 0.3 \\
8\end{array}$ & $\begin{array}{c}29.98 \pm 0.6 \\
1\end{array}$ & $\begin{array}{c}64.78 \pm 0.7 \\
1\end{array}$ & $\begin{array}{c}14.77 \pm 0 \\
24\end{array}$ & $\begin{array}{c}42.91 \pm 0.4 \\
6\end{array}$ & $\begin{array}{c}15.93 \pm 0.3 \\
9\end{array}$ \\
\hline E13 & 0 & 0 & 0 & $85: 15$ & 7 & 0.30 & $\begin{array}{c}55.68 \pm 0.3 \\
1\end{array}$ & $\begin{array}{c}16.42 \pm 0.0 \\
9\end{array}$ & $\begin{array}{c}31.57 \pm 0.1 \\
9\end{array}$ & $\begin{array}{c}69.05 \pm 0.9 \\
1\end{array}$ & $\begin{array}{c}15.61 \pm 0 . \\
04\end{array}$ & $\begin{array}{c}49.15 \pm 0.3 \\
7\end{array}$ & $\begin{array}{c}22.12 \pm 1.1 \\
3\end{array}$ \\
\hline E14 & 0 & 0 & 0 & $85: 15$ & 7 & 3.70 & $\begin{array}{c}58.84 \pm 0.9 \\
8\end{array}$ & $\begin{array}{c}14.83 \pm 0.3 \\
1\end{array}$ & $\begin{array}{c}30.24 \pm 0.3 \\
8\end{array}$ & $\begin{array}{c}69.27 \pm 0.6 \\
1\end{array}$ & $\begin{array}{c}14.16 \pm 0 . \\
29\end{array}$ & $\begin{array}{c}43.42 \pm 0.6 \\
4\end{array}$ & $\begin{array}{c}16.86 \pm 1.1 \\
5\end{array}$ \\
\hline $\begin{array}{l}\text { E15 } \\
(C)\end{array}$ & 0 & 0 & 0 & $85: 15$ & 7 & 2 & $\begin{array}{c}55.31 \pm 0.1 \\
5\end{array}$ & $\begin{array}{c}16.84 \pm 0.5 \\
0\end{array}$ & $\begin{array}{c}32.01 \pm 0.5 \\
8\end{array}$ & $\begin{array}{c}69.31 \pm 0.6 \\
6\end{array}$ & $\begin{array}{c}15.59 \pm 0 . \\
26\end{array}$ & $\begin{array}{c}45.24 \pm 0.1 \\
3\end{array}$ & $\begin{array}{c}19.31 \pm 1.0 \\
2\end{array}$ \\
\hline $\begin{array}{l}\text { E16 } \\
(C)\end{array}$ & 0 & 0 & $\begin{array}{c}- \\
1.6 \\
8\end{array}$ & $85: 15$ & 7 & 2 & $\begin{array}{c}55.17 \pm 0.8 \\
3\end{array}$ & $\begin{array}{c}16.53 \pm 0.1 \\
9\end{array}$ & $\begin{array}{c}31.82 \pm 0.5 \\
1\end{array}$ & $\begin{array}{c}68.90 \pm 0.3 \\
4\end{array}$ & $\begin{array}{c}15.41 \pm 0 \\
23\end{array}$ & $\begin{array}{c}44.63 \pm 0.4 \\
0\end{array}$ & $\begin{array}{c}18.83 \pm 0.6 \\
1\end{array}$ \\
\hline $\begin{array}{r}\text { E17 } \\
(\mathrm{C}) \\
\end{array}$ & 0 & 0 & $\begin{array}{c}1.6 \\
8 \\
\end{array}$ & $85: 15$ & 7 & 2 & $\begin{array}{c}54.71 \pm 0.5 \\
3 \\
\end{array}$ & $\begin{array}{c}16.95 \pm 0.4 \\
7 \\
\end{array}$ & $\begin{array}{c}31.08 \pm 0.0 \\
2\end{array}$ & $\begin{array}{c}68.77 \pm 0.4 \\
6\end{array}$ & $\begin{array}{c}15.22 \pm 0 \\
05\end{array}$ & $\begin{array}{c}44.49 \pm 0.2 \\
1\end{array}$ & $\begin{array}{c}19.51 \pm 0.3 \\
5\end{array}$ \\
\hline & & & $\mathbf{R}^{\mathrm{c}}$ & & & & 0.58 & 0.64 & 0.65 & 0.66 & 0.94 & 0.76 & $\mathrm{ND}^{\mathrm{e}}$ \\
\hline & & & p-val & & & & 0.47 & 0.34 & 0.00 & 0.29 & 0.00 & 0.00 & $\mathrm{ND}^{\mathrm{e}}$ \\
\hline & & & ack & & & & 0.00 & 0.01 & 0.16 & 0.00 & 0.06 & 0.04 & $\mathrm{ND}^{\mathrm{e}}$ \\
\hline & & Pure e & cor $\mathbf{m}$ & n squar & & & 0.10 & 0.00 & 0.20 & 0.00 & 0.10 & 0.20 & $\mathrm{ND}^{\mathrm{e}}$ \\
\hline & & Mean \pm & tanda & deviati & & & $\begin{array}{c}53.95 \pm 3.7 \\
7 \\
\end{array}$ & $\begin{array}{c}16.10 \pm 1.7 \\
4\end{array}$ & $\mathrm{ND}^{\mathrm{e}}$ & $\begin{array}{c}66.81 \pm 3.9 \\
0\end{array}$ & $\mathrm{ND}^{\mathrm{e}}$ & $\begin{array}{c}43.32 \pm 3.0 \\
7 \\
\end{array}$ & $\mathrm{ND}^{\mathrm{e}}$ \\
\hline
\end{tabular}

${ }^{\mathrm{a}} \mathrm{C}$ : Central point. ${ }^{\mathrm{b}}$ Coded values, were: $\mathrm{x}_{1}=$ proportions $(\mathrm{g} / 100 \mathrm{~g})$ of the mixture of rice flour and biofortified sweet potato flour $(\mathrm{RF}: \mathrm{BSPF}) ; \mathrm{x}_{2}=$ amount of hydrolyzed soy protein concentrate (HSPC, $\mathrm{g} / 100 \mathrm{~g}$ of RF:BSPF; $\mathrm{x}_{3}=$ amount of sodium carboxymethylcellulose gum (CMC, $\mathrm{g} / 100 \mathrm{~g}$ of RF:BSPF). ${ }^{c}$ Values as mean \pm standard deviation (triplicate). ${ }^{\mathrm{d}} \mathrm{L}^{*}$ : lightness; $\mathrm{a}^{*}$ : positive values (red) and negative values (green); $b^{*}$ : positive values (yellow) and negative values (blue); $\triangle \mathrm{E}$ : the color difference between raw and cooked GFP. Source: Authors. 
Figure 3. Response surfaces for technological attributes of fusilli-type gluten-free pastas (GFPs), were:3(a) b* raw GFP parameter of color; 3 (b) a* cooked GFP parameter of color; 3 (c, d, and e): diameter of GFPs; 3(f): unit size of GFPs.

(a)

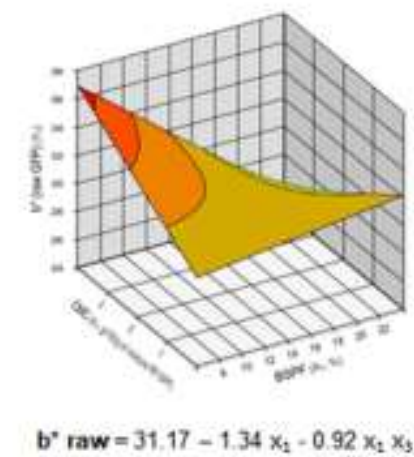

(c)

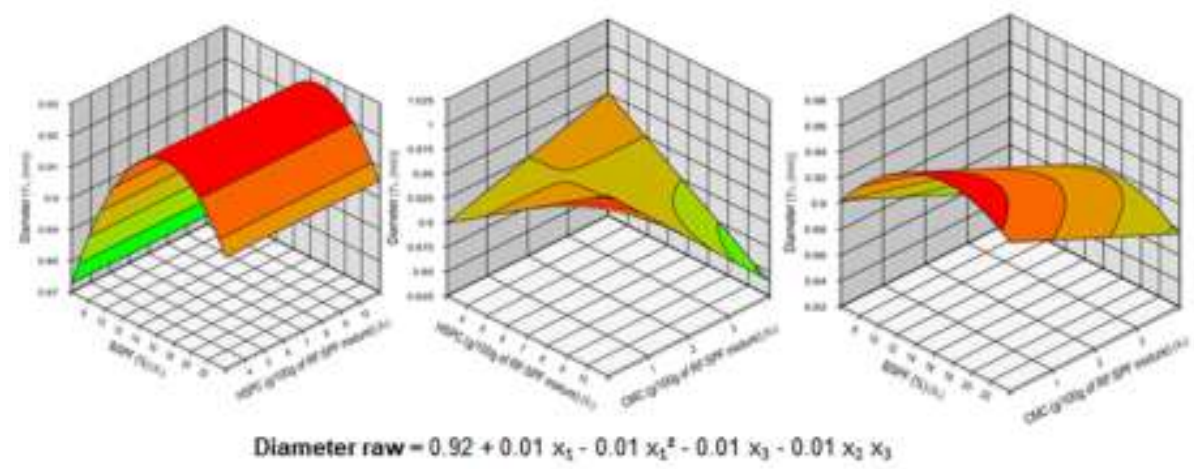

(b)

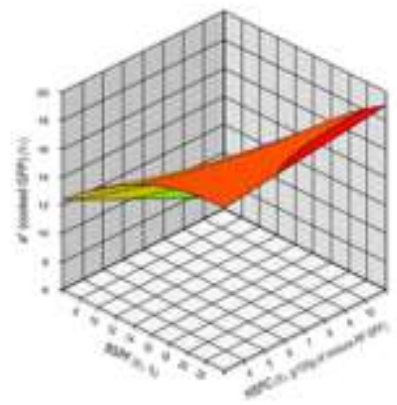

$a^{*}$ cooked $=15.26+2.41 x_{1}+0.42 x_{1}^{3}+0.50 x_{2}+0.49 x_{1} x_{2}$

(f)

Source: Authors.

\subsection{Quality assessment}

The results of the technological evaluation of raw GFPs (size, diameter, and pitch), as well its correspondent mean, standard deviation, coefficient of correlation $\left(\mathrm{R}^{2}\right)$, significance ( $\mathrm{p}$-value), lack of fit, mean square pure error, and adjusted models are shown in Table 4. By the response surfaces (Figure 3), it was possible to verify that there were interactions between the ingredients and modifications on their proportions affected the structure of the GFPs. For the parameter diameter of the raw GFPs, a significant effect was observed for the RF:BSPF ratio, the CMC concentration, and the interaction between HSPC and $\mathrm{CMC}$, as shown in the response surface in Figure $3\left(\mathrm{c}, \mathrm{d}\right.$, and e). It was a tendency $\left(\mathrm{R}^{2}<0.80\right)$ to a higher diameter of the unit of the GFPs, due to the increase in BSPF and decrease in RF concentrations, probably due to the different properties of cereals and root starch granules. The processing conditions may have also affected these results, once BSP was previously bleached to produce the BSPF, which may have led to the formation of pregelatinized starch, characterized by rapid water absorption and swelling during the hydration and shape process (cold extrusion) of the GFPs. Regarding the unit size, a significant effect was observed for CMC, as shown in Figure 3(f), with a tendency $\left(\mathrm{R}^{2}<0.80\right)$ of increasing the unit size, with higher values of CMC. The pitch of the units of the GFPs could be not statistically evaluated due to severe defects in the shape of E8 and E14. It was observed that the increase of HSPC associated to a reduction of CMC resulted in GFPs with lower pitch values (classified as "narrow"), and prone to cracks and defects, what are not desirable aspects for these products. 
Research, Society and Development, v. 10, n. 4, e21310413959, 2021

(CC BY 4.0) | ISSN 2525-3409 | DOI: http://dx.doi.org/10.33448/rsd-v10i4.13959

Table 4. Technological characteristics of fusilli-type gluten-free pastas ${ }^{\mathrm{a}, \mathrm{b}}$

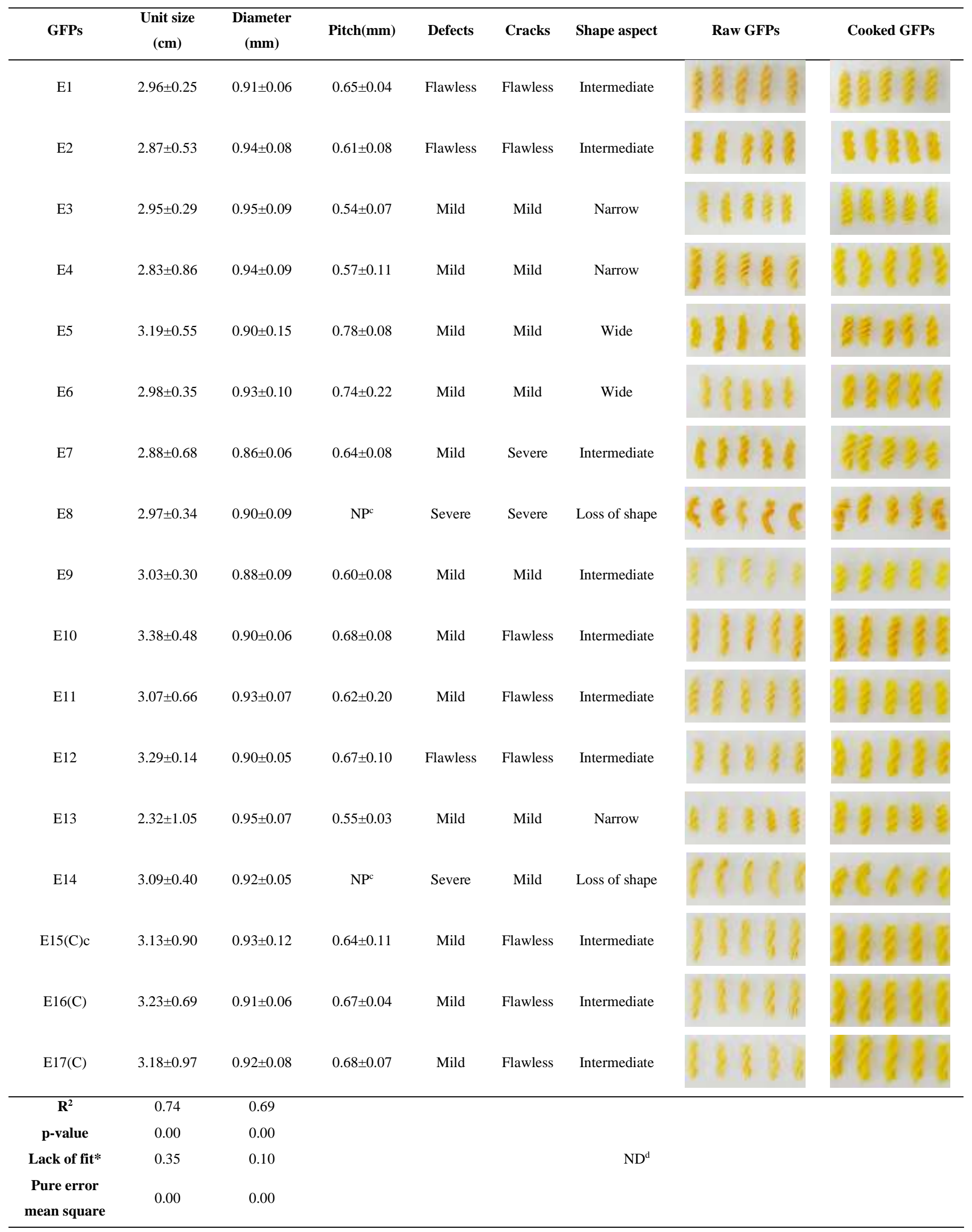

${ }^{\mathrm{a}} \mathrm{GFPs}=$ Gluten-free pastas; $\mathrm{C}=$ central points. ${ }^{\mathrm{b}}$ Values as mean \pm standard deviation obtained from the sampling of 15 GFPs units. ${ }^{\mathrm{c}} \mathrm{NP}$ : It was not possible to evaluate. ${ }^{\mathrm{d} N D}$ : not determined. Source: Authors. 


\subsection{Gluten-free pasta selection}

From the visual analysis data (Table 4), the GFPs were analyzed for their technological properties, and according to the selection criteria - absence of breaks or defects, and intermediate shape aspect after cooking - it was possible to select three GFPs: E1, E2, and E12.

\subsection{Physicochemical composition of the selected gluten-free pasta}

The results of the proximate composition of GFPs are shown in Table 5. The moisture content of the GFPs was less than $14 \mathrm{~g} / 100 \mathrm{~g}$, which is important to prevent microbial growth and extend the shelf life of the products at room temperature.

As expected, the differences in the concentrations of the ingredients between the formulations led to changes in the proximate composition of GFPs.

For the protein content, the E12 differed statistically from the others GFPs, which can be attributed to the greater addition of HSPC. However, the three GFPs presented a high quantity of protein when compared to those found by other studies. For example, GFPs with sorghum, rice, potatoes and eggs, presented 7.86 to $8.85 \%$ of protein in their centesimal composition (Ferreira et al. 2019).

For the lipids content, there was observed an increase of lipids probably associated to the increase of the BSPF. The lipid fraction is important for the GFP because it concentrates the liposoluble compounds, such as provitamin A (Sousa et al. 2020), and that should be considered for packaging choice and storage conditions. It was observed that the ash content was higher in E2 and E12, which can be attributed to the mineral content present in the BSP peel, and which is also include in the BSPF processing.

For the composition of the GFPs, we considered only the fiber content present in BSPF, which was higher with the increase of this flour. Pasta, particularly GFP, is rich in carbohydrates due to the flours and starches used in its composition, which may be derived from cereals, pseudo cereals, roots or tubers. These sources are important for the structuring of the GFP, from the gelatinization and retrogradation of the available starch that occurs during cooking and cooling (Marti and Pagani 2013). The fragments of fiber could impair the GFP structure, leading to a brittle surface. On the other hand, the fiber is important for a slower digestion, and have many benefits for the digestive health.

\subsection{Functional analysis}

According to Table 5, E2 had the highest $\beta$-carotene level, with a significant difference from the others. This formulation contained the highest BSPF concentration $(20 \mathrm{~g} / 100 \mathrm{~g})$, suggesting that BSPF contributed to the increase in provitamin A levels in GFPs. Limroongreungrat \& Huang (2007) studied dry GFPs and found a $\beta$-carotene level of $900 \mu \mathrm{g} / \mathrm{g}$ in the control made with $10 \mathrm{~g} / 100 \mathrm{~g}$ of BSPF. However, these results were for raw GFPs, without considering the carotenoid losses by the cooking processes, that could reduce the amount of this carotenoid. 
Table 5. Chemical composition of fusilli-shape gluten-free pastas ${ }^{a}$

\begin{tabular}{|c|c|c|c|}
\hline \multirow{2}{*}{ Compounds(g/100g) } & \multicolumn{3}{|c|}{ Gluten-free pastas $^{\mathrm{b}, \mathrm{c}}$} \\
\hline & $\mathbf{E 1}^{\mathrm{d}}$ & $\mathbf{E 2}^{\mathrm{d}}$ & E12 $^{\mathrm{d}}$ \\
\hline Moisture & $9.00 \pm 0.27 \mathrm{~b}$ & $7.99 \pm 0.03 \mathrm{c}$ & $9.93 \pm 0.30 \mathrm{a}$ \\
\hline Dry matter & 91.00 & 92.01 & 90.07 \\
\hline Protein & $10.53 \pm 0.63 b$ & $11.97 \pm 1.00 \mathrm{ab}$ & $12.70 \pm 0.54 \mathrm{a}$ \\
\hline Lipids & $1.47 \pm 0.02 \mathrm{c}$ & $1.61 \pm 0.04 \mathrm{a}$ & $1.54 \pm 0.02 b$ \\
\hline Ash & $1.21 \pm 0.01 \mathrm{c}$ & $1.69 \pm 0.02 \mathrm{~b}$ & $1.75 \pm 0.01 \mathrm{a}$ \\
\hline Digestible carbohydrates ${ }^{d}$ & 76.68 & 74.52 & 72.41 \\
\hline Total dietary fiber ${ }^{\mathrm{e}}$ & 1.11 & 2.22 & 1.67 \\
\hline$\beta$-carotene $(\mu \mathrm{g} / \mathrm{g})$ & $135.22 \pm 6.95 b$ & $292.04 \pm 16.64 a$ & $147.54 \pm 22.95 b$ \\
\hline
\end{tabular}

${ }^{a}$ Results were expressed as mean \pm standard deviation (triplicate), on a dry basis. ${ }^{b}$ Different lowercase letters in the same column indicate significant differences $(\mathrm{p} \leq 0.05)$ by Tukey's test. ${ }^{\circ} \mathrm{Gluten}$-free pasta formulation, based on rice flour $(\mathrm{RF})$, biofortified sweet potato flour (BSPF), with addition of hydrolyzed soy protein concentrate (HSPC) and carboxymethyl cellulose gum (CMC): E1= 90g RF, 10g BSPF, 5g HSPC, 1g CMC; E2= 80:20 RF:BSPF, 5g HSPC, 1g CMC, E12 =85g RF, 15g BSPF, 10.40g HSPC, 2g CMC. ${ }^{\mathrm{d} C a r b o h y d r a t e s ~ d e t e r m i n e d ~ b y ~}$ difference (100 - (moisture+proteins+lipids+ash+total dietary fiber)). ${ }^{\mathrm{e}}$ Total dietary fiber content of GFP was calculated considering only the BSPF as an ingredient source of dietary fiber (13.02 $\pm 0.88 \mathrm{~g} / 100 \mathrm{~g}$ of BSPF, dry basis). Source: Authors.

\subsection{Sensory evaluation}

According to the questionnaire about pasta consumption habits, for the frequency of consumption, $7 \%$ of the consumers usually eat pasta 3 to 4 times a week; 56\%, 1 to 2 times a week; 28\%, 1 time every 15 days, and 9\%, once a month. The questionnaire suggested eight options of pasta, and consumers should select the three types that were most consumed. The results showed that $72 \%$ of the consumers usually eat pasta with eggs; $61 \%$, dry pasta; and $46 \%$, fresh commercial pasta. Regarding the consumption of GFPs, $65 \%$ never consumed gluten-free pasta; $23 \%$, only once; $10 \%$, occasionally; and $2 \%$, frequently.

Table 6 presents the results of the sensory evaluation of raw GFPs. There was no significant difference ( $>0.05)$ among the GFPs for overall liking, that presented means in acceptance region (>4.5), indicating good acceptance scores. It is worth mentioning that the GFPs of this study were consumed without the addition of sauce or seasoning, despite the popular consumption habit, aiming to focus on the color and texture sensory perception and reduce the interference of other ingredients on these attributes.

\subsubsection{Penalty Analysis}

The results from the penalty analysis of the raw and cooked GFPs are shown in Table 7. For color, most consumers considered the raw GFPs E2 "too much dark", with higher penalty values. Considering the most experience from the assessors were related to the conventional semolina-based pastas, which color are close to a mild yellow, they may have evaluated negatively the GFP E2 even before tasting due to its orange color, derived from its higher BSPF content (20g/100g BSPF:RF). However, most assessors evaluated the cooked E2 this attribute with better notes due to the color modifications caused by carotenoid degradation by heat, and water absorption. It is interesting to notice that for E12, this behavior not occurred, and the penalty had increased for the GFP after cooking. We have to consider that in its formulation, it is present a higher amount of HSPC and less BSPF in comparison to E2, that has a slight dark color after cooking, that could be highlighted after carotenoids degradation. 
Table 6. Sensory attributes of acceptance of raw and cooked fusilli-type gluten-free pasta (GFP).

\begin{tabular}{|c|c|c|c|c|c|}
\hline \multirow{2}{*}{ GFP } & \multirow{2}{*}{ Attribute } & \multicolumn{3}{|c|}{ GFPa $^{\mathbf{a}}$} & \multirow{2}{*}{ p-value } \\
\hline & & E1 & E2 & E12 & \\
\hline \multirow[t]{3}{*}{ Raw } & \multirow{2}{*}{ Appearance } & $5.88 \pm 1.87$ & $5.72 \pm 2.02$ & $6.06 \pm 2.03$ & 0.61 \\
\hline & & $6.22 \pm 1.91$ & $5.89 \pm 2.08$ & $5.88 \pm 2.05$ & 0.60 \\
\hline & Aroma & $6.53 \pm 1.74$ & $5.91 \pm 2.00$ & $6.02 \pm 1.97$ & 0.19 \\
\hline \multirow[t]{3}{*}{ Cooked } & Flavor & $4.83 \pm 2.27$ & $5.09 \pm 2.21$ & $4.61 \pm 2.05$ & 0.49 \\
\hline & Texture & $4.25 \pm 2.41$ & $4.75 \pm 2.42$ & $3.77 \pm 2.33$ & 0.10 \\
\hline & Overall liking & $4.97 \pm 1.97$ & $5.03 \pm 2.09$ & $4.66 \pm 1.89$ & 0.57 \\
\hline
\end{tabular}

${ }^{\mathrm{a} C}$ Composition of GFP: E1 = RF:BSPF (proportion 90:10), HSPC (5g/100g of RF:BSPF mixture), and CMC (1g/100g); E2 = RF:BSPF (80:20), $\operatorname{HSPC}(5 \mathrm{~g} / 100 \mathrm{~g}), \mathrm{CMC}(1 \mathrm{~g} / 100 \mathrm{~g}), \mathrm{E} 12$ = RF:BSPF $(85: 15), \mathrm{HSPC}(10.40 \mathrm{~g} / 100 \mathrm{~g}), \mathrm{CMC}(2 \mathrm{~g} / 100 \mathrm{~g})$, where: RF = rice flour; BSPF = biofortified sweet potato flour; HSPC $=$ hydrolyzed soy protein concentrate. Data expressed as mean \pm standard deviation $(\mathrm{n}=119)$. Values from a $9 \mathrm{~cm}$ nonstructured hedonic scale, were: $\geq 4.5=$ acceptation region; $4.5=$ neutrality; $\leq 4.5=$ rejection region; ( $\mathrm{p} \geq 0.05$, by Tukey's test). Source: Authors.

The results from the penalty analysis of the overall liking were also assessed for the attribute consistency. For E1, 47.4\% of the assessors considered the texture "too much soft" and 35.1\% rated that the sample as "too much firm". Although both effects were significant $(\mathrm{p}<0.05)$, higher penalty scores were observed for the descriptor "too much soft", with an effect on the mean value of 3.17 , probably due to the different cooking habits and more frequent consumption of conventional wheat-based pasta. It was observed that the E2, which presented the major quantity of the BSPF, was the only that did not have a penalization of the overall liking means due to the consistency aspect, which could highlight the potential of the BSPF as an ingredient for GFPs. 
Table 7. Penalty analysis and "Just-about-right" (JAR) scale for color and consistency of cooked fusilli gluten-free pasta (GFP).

\begin{tabular}{|c|c|c|c|c|c|c|c|c|}
\hline GFPa $^{a}$ & Type & $\begin{array}{c}\text { Classification } \\
\text { options }\end{array}$ & $\begin{array}{c}\text { Consumers } \\
(\%)\end{array}$ & $\begin{array}{l}\text { Overall } \\
\text { Liking }^{b}\end{array}$ & $\begin{array}{c}\text { Effect } \\
\text { on } \\
\text { mean } \\
\text { value }\end{array}$ & $\begin{array}{c}\text { p- } \\
\text { value }^{c}\end{array}$ & $\begin{array}{c}\text { Penaltie } \\
\text { s }\end{array}$ & p-value \\
\hline \multirow{11}{*}{ E1 } & \multirow{4}{*}{ Raw } & \multicolumn{7}{|c|}{ Color } \\
\hline & & Too light color & 52.6 & 5.28 & 1.83 & $0.01^{\mathrm{d}}$ & & \\
\hline & & JAR & 24.6 & 7.11 & & & 1.63 & $0.00^{\mathrm{d}}$ \\
\hline & & Too much dark & 22.8 & 5.93 & 1.18 & 0.20 & & \\
\hline & \multirow{7}{*}{ Cooked } & Too light color & 33.3 & 4.81 & 0.48 & 0.43 & \multirow{3}{*}{0.64} & \multirow{3}{*}{0.23} \\
\hline & & JAR & 49.1 & 5.29 & & & & \\
\hline & & Too much dark & 17.5 & 4.36 & 0.93 & $\mathrm{NC}^{\mathrm{e}}$ & & \\
\hline & & \multicolumn{7}{|c|}{ Consistency } \\
\hline & & Too much soft & 47.4 & 3.96 & 3.17 & $<0.00^{\mathrm{d}}$ & \multirow{3}{*}{2.62} & \multirow{3}{*}{$<0.00^{\mathrm{d}}$} \\
\hline & & JAR & 17.5 & 7.13 & & & & \\
\hline & & Too much firm & 35.1 & 5.24 & 1.89 & $0.01^{\mathrm{d}}$ & & \\
\hline \multirow{11}{*}{$\mathbf{E} 2$} & \multirow{4}{*}{ Raw } & \multicolumn{7}{|c|}{ Color } \\
\hline & & Too light color & 14.0 & 5.26 & 2.53 & $\mathrm{NC}^{\mathrm{e}}$ & \multirow{3}{*}{2.51} & \multirow{3}{*}{$0.00^{\mathrm{d}}$} \\
\hline & & JAR & 17.5 & 7.79 & & & & \\
\hline & & Too much dark & 68.4 & 5.28 & 2.51 & $0.00^{\mathrm{d}}$ & & \\
\hline & \multirow{7}{*}{ Cooked } & Too light color & 33.3 & 4.81 & 0.48 & 0.43 & \multirow{3}{*}{0.64} & \multirow{3}{*}{0.23} \\
\hline & & JAR & 49.1 & 5.29 & & & & \\
\hline & & Too much dark & 17.5 & 4.36 & 0.93 & $\mathrm{NC}^{\mathrm{e}}$ & & \\
\hline & & \multicolumn{7}{|c|}{ Consistency } \\
\hline & & Too much soft & 31.6 & 4.57 & 1.69 & 0.14 & \multirow{3}{*}{1.44} & \multirow{3}{*}{0.07} \\
\hline & & JAR & 14.0 & 6.26 & & & & \\
\hline & & Too much firm & 54.4 & 4.97 & 1.29 & 0.27 & & \\
\hline \multirow{11}{*}{ E12 } & \multirow{4}{*}{ Raw } & \multicolumn{7}{|c|}{ Color } \\
\hline & & Too light color & 19.3 & 5.42 & 1.46 & $\mathrm{NC}^{\mathrm{e}}$ & \multirow{3}{*}{1.05} & \multirow{3}{*}{0.12} \\
\hline & & JAR & 21.1 & 6.88 & & & & \\
\hline & & Too much dark & 59.7 & 5.97 & 0.91 & 0.15 & & \\
\hline & \multirow{7}{*}{ Cooked } & Too light color & 14.0 & 4.89 & 0.78 & $\mathrm{NC}^{\mathrm{e}}$ & \multirow{3}{*}{1.34} & \multirow{3}{*}{$0.02^{\mathrm{d}}$} \\
\hline & & JAR & 24.6 & 5.67 & & & & \\
\hline & & Too much dark & 61.4 & 4.20 & 1.47 & 0.01 & & \\
\hline & & & & Consiste & & & & \\
\hline & & Too much soft & 33.3 & 3.84 & 1.98 & $0.02^{\mathrm{d}}$ & & \\
\hline & & JAR & 15.8 & 5.82 & & & 1.38 & $0.04^{\mathrm{d}}$ \\
\hline & & Too much firm & 50.9 & 4.83 & 0.99 & 0.33 & & \\
\hline
\end{tabular}

${ }^{a}$ GFP composition: E1 = RF:BSPF (proportion 90:10), HSPC (5g/100gof RF:BSPF mixture), and CMC (1g/100g of RF:BSPF); E2 = RF:BSPF (80:20), HSPC (5g/100g of RF:BSPF), CMC (1g/100g of RF:BSPF), E12 = RF:BSPF (85:15), HSPC (10.40g/100g of RF:BSPF), CMC $\left(2 \mathrm{~g} / 100 \mathrm{~g}\right.$ of RF:BSPF), where: $\mathrm{RF}=$ rice flour; $\mathrm{BSPF}=$ biofortified sweet potato flour; $\mathrm{HSPC}=$ hydrolyzed soy protein concentrate. ${ }^{\mathrm{b}} \mathrm{Using}$ a 9 $\mathrm{cm}$ non-structured hedonic scale, were: $\geq 4.5=$ acceptation region; $4.5=$ neutrality; $\leq 4.5=$ rejection region. ${ }^{\mathrm{c}, \mathrm{d}}$ Significative $\mathrm{p}$-value $(95 \%$ of confidence interval using Tukey's range test). ${ }^{\mathrm{e}} \mathrm{NC}=$ not calculated (quantity of responses $<20 \%$ ). Source: Authors.

\section{Conclusion}

This study showed that it is possible to use the biofortified sweet potato flour to give yellow color, regional flavor, good sensory acceptance and increase of the protein and $\beta$-carotene content of rice flour-based GFPs with hydrolyzed soy protein concentrate and carboxymethylcellulose gum. The increase in the consumption and processing of the biofortified sweet potato 
can also promote a social benefit, by stimulating its growth by smallholder farmers. Further studies can be made in other formats, mainly for short pastas, using this ingredient combination, because there is also a lack of tasteful GFP with attractive appearance, and rich in vitamins. It could be stimulated studies with other sources of proteic ingredients, or hydrocolloids.

\section{Acknowledgments}

The authors thank the EMBRAPA BioFORT program for the donation of biofortified sweet potatoes, and Fazenda Pau d'Alho for planting; the food companies: SL Alimentos, HT Nutri, CPKelco, and Danisco for the donation of the raw materials to produce the GFPs; Mr. Emerson A. Scarton for language help and photo editing. This work was supported by the Coordenação de Aperfeiçoamento de Pessoal de Nível Superior program (Grant number 001) and Conselho Nacional de Desenvolvimento Científico e Tecnológico -CNPq (Grant number 140791/2017-5 and 150826/2019-2).

\section{References}

AACCI. (2010). Approved Methods of Analysis. AACC International.

AOAC. (2005). Official Methods of Analysis; (15th ed.). Association of Official Analytical Chemists.

Berni, P., Chitchumroonchokchai, C., Canniatti-Brazaca, S. G., De Moura, F. F., \& Failla, M. L. (2015). Comparison of Content and In vitro Bioaccessibility of Provitamin A Carotenoids in Home Cooked and Commercially Processed Orange Fleshed Sweet Potato (Ipomea batatas Lam). Plant Foods for Human Nutrition, 70(1), 1-8. https://doi.org/10.1007/s11130-014-0458-1

Bohoyo-Gil, D., Dominguez-Valhondo, D., García-Parra, J. J., \& González-Gómez, D. (2012). UHPLC as a suitable methodology for the analysis of carotenoids in food matrix. European Food Research and Technology, 235(6), 1055-1061. https://doi.org/10.1007/s00217-012-1838-0

Bouasla, A., Wójtowicz, A., \& Zidoune, M. N. (2017). Gluten-free precooked rice pasta enriched with legumes flours: Physical properties, texture, sensory attributes and microstructure. LWT - Food Science and Technology, 75, 569-577. https://doi.org/10.1016/j.1wt.2016.10.005

Brouns, F. J. P. H., van Buul, V. J., \& Shewry, P. R. (2013). Does wheat make us fat and sick? Journal of Cereal Science, 58(2), 209-215. https://doi.org/10.1016/j.jcs.2013.06.002

Campos, B. V. P., Almeida, E. L. (2020). Gluten-free pasta elaborated with taro flour (Colocasia esculenta): a study of the employ of egg white and transglutaminase on the technological properties. Research, Society and Development, 10(1), e52710111454, 1-13. http://dx.doi.org/10.33448/rsd-v10i1.11454

Cardenas-Toro, F. P., Alcázar-Alay, S. C., Coutinho, J. P., Godoy, H. T., Forster-Carneiro, T., \& Meireles, M. A. A. (2015). Pressurized liquid extraction and low-pressure solvent extraction of carotenoids from pressed palm fiber: Experimental and economical evaluation. Food and Bioproducts Processing, 94, 90100. https://doi.org/10.1016/j.fbp.2015.01.006

Ferreira, S. M. R., de Mello, A. P., de Caldas Rosa dos Anjos, M., Krüger, C. C. H., Azoubel, P. M., \& de Oliveira Alves, M. A. (2016). Utilization of sorghum, rice, corn flours with potato starch for the preparation of gluten-free pasta. Food Chemistry, 191, 147-151. https://doi.org/10.1016/j.foodchem.2015.04.085

Gödecke, T., Stein, A. J., \& Qaim, M. (2018). The global burden of chronic and hidden hunger: Trends and determinants. Global Food Security, 17, 21-29. https://doi.org/10.1016/j.gfs.2018.03.004

Julianti, E., Rusmarilin, H., Ridwansyah, \& Yusraini E. (2017). Functional and rheological properties of composite flour from sweet potato, maize, soybean and xanthan gum. Journal of the Saudi Society of Agricultural Sciences, 16, 171-177. https://doi.org/10.1016/j.jssas.2015.05.005

Kissler, S. M., Tedijanto, C., Goldstein, E., Grad, Y. H., \& Lipsitch, M. (2020). Projecting the transmission dynamics of SARS-CoV-2 through the postpandemic period. Science, 368(6493), 860-868. https://doi.org/10.1126/science.abb5793

Lamacchia, C., Camarca, A., Picascia, S., Di Luccia, A., \& Gianfrani, C. (2014). Cereal-Based Gluten-Free Food: How to Reconcile Nutritional and Technological Properties of Wheat Proteins with Safety for Celiac Disease Patients. Nutrients, 6(2), 575-590. https://doi.org/10.3390/nu6020575]

Lawless, H. T., \& Heymann, H. (2010). Sensory evaluation of food: principles and practices. Springer, 850 p.

Limroongreungrat, K., \& Huang, Y.-W. (2007). Pasta products made from sweetpotato fortified with soy protein. LWT - Food Science and Technology, 40(2), 200-206. https://doi.org/10.1016/j.lwt.2005.09.012

Marti, A., \& Pagani, M. A. (2013). What can play the role of gluten in gluten free pasta? Trends in Food Science \& Technology, 31(1), 63-71. https://doi.org/10.1016/j.tifs.2013.03.001

Meilgaard, M., Civille, G. V., \& Carr, B. T. (2000). Sensory Evaluation Techniques (3rd ed.). CRC Press.

Mokrzycki, W., \& Tatol, M. (2011). Color difference Delta E: a survey. Machine Graphics and Vision, 20, $383-411$.

Morais, E. C., Morais, A. R., Cruz, A. G., \& Bolini, H. M. A. (2014). Development of chocolate dairy dessert with addition of prebiotics and replacement of sucrose with different high-intensity sweeteners. Journal of Dairy Science, 97(5), 2600-2609. https://doi.org/10.3168/jds.2013-7603 
Research, Society and Development, v. 10, n. 4, e21310413959, 2021

(CC BY 4.0) | ISSN 2525-3409 | DOI: http://dx.doi.org/10.33448/rsd-v10i4.13959

Nutti, M. R. (2003). A história dos projetos HarvestPlus, AgroSalud e BioFORT no Brasil. IV Reunião de Biofortificação, 1, 1-12.

Pathare, P. B., Opara, U. L., \& Al-Said, F. A.-J. (2013). Colour Measurement and Analysis in Fresh and Processed Foods: A Review. Food and Bioprocess Technology, 6(1), 36-60. https://doi.org/10.1007/s11947-012-0867-9

Rodrigues-Amaya, D., \& Kimura, M. (2004). Harvest Plus Handbook for carotenoid analysis. Harvest Plus Technical Monograph.

Sousa, L. B. T., Soares, M. G. L., Minguita, A. P. S., Carvalho, J. L.V., \& Moraes, E. A. (2020). Addition of lipids to cookies containing orange-fleshed sweet potatoes increases carotenoid retention. Research, Society and Development, 9, 12, e8191210964, 1-15. http://dx.doi.org/10.33448/rsd-v9i12.10964

Souza, D. G., Resende, O. Pilon, L., Cabral, J. C. O., \& Resende, L. F. L. (2020). Caracterização físico-química e tecnológica de farinha de batata-doce biofortificada seca em diferentes temperaturas. Research, Society and Development, 9(11), e63391110386, 1-14. http://dx.doi.org/10.33448/rsd-v9i11.10386

Sun, X. D. (2011). Enzymatic hydrolysis of soy proteins and the hydrolysates utilisation. International Journal of Food Science \& Technology, 46(12), 24472459. https://doi.org/10.1111/j.1365-2621.2011.02785.x

Taylor, J. R. N., \& Duodu, K. G. (2017). Sorghum and Millets: Grain-Quality Characteristics and Management of Quality Requirements. In C. Wrigley, I. Batey, \& D. Miskelly (Eds.), Cereal Grains (First, pp. 317-351). Woodhead Publishing.

UNICEF. (2019). The State of the World's Children 2019. In Children, Food and Nutrition: Growing well in a changing world. UNICEF.

Wahanik, A. L. Neri-Numa, I. A., Pastore, G. M., Felisberto, M. H. F., Campelo, P. H., \& Clerici, M. T. P. S. (2021). Technological and antioxidant characteristics of pasta with whole wheat flour and natural colored concentrates. Research, Society and Development, 10(3), e7110312072, 1-11. http://dx.doi.org/10.33448/rsdv10i3.13072

Xue, J., \& Ngadi, M. (2007). Rheological properties of batter systems containing different combinations of flours and hydrocolloids. Journal of the Science of Food and Agriculture, 87(7), 1292-1300. https://doi.org/10.1002/jsfa.2845 